\title{
INVESTIGATION AND EVALUATION OF THE QUALITY FEATURES RELATED TO COMFORT OF CASUAL SHOES IN BANGLADESHI LEADING RETAIL BRANDS USING PHYSICAL AND CHEMICAL STANDARD TEST METHODS
}

\author{
Md. Rayhan SARKER, Amal Kanti DEB*, Manjushree CHOWDHURY*, Md. Israil HOSSAIN \\ Institute of Leather Engineering and Technology, University of Dhaka, Dhaka-1209, Bangladesh, \\ md.sarkerdu.rayhan@gmail.com, debak.ilet@du.ac.bd, manjushreechow@gmail.com, israil.rafi@yahoo.com
}

Received: 03.01.2019

Accepted: 17.02.2019

https://doi.org/10.24264/lfj.19.1.2

\section{INVESTIGATION AND EVALUATION OF THE QUALITY FEATURES RELATED TO COMFORT OF CASUAL SHOES IN BANGLADESHI LEADING} RETAIL BRANDS USING PHYSICAL AND CHEMICAL STANDARD TEST METHODS

ABSTRACT. Several materials and chemicals are being used during manufacturing processes of shoes which are responsible for a good quality product. Nowadays it has been coming out of the current market of Bangladesh that leading retail brands are not providing good quality footwear to their customers. The aim of the study was to investigate different physical and chemical properties of sample shoe materials related to comfort features. Ten pairs of casual leather shoes were brought from five leading Bangladeshi retail brand outlets focusing on equal price point and best-selling article. These samples underwent different physical and chemical tests following standard methods of SATRA (Shoe and Allied Trade Research Association), IUP (International Union for Physical testing) and SLC (Society of Leather Chemists) such as whole shoe flexing, sole adhesion, flexing endurance of upper materials, SATRA-Bata sole flexing, shrinkage temperature, percentage of chromium (expressed as \% Cr2O3) content, water absorbency, water vapor permeability (W.V.P) and pH. All samples showed poor sole adhesion as average separation load were recorded $13.9 \mathrm{~kg}, 14.2 \mathrm{~kg}$ and $20.1 \mathrm{~kg}$ at the toe, ball and heel areas respectively that were far below than standard values. Three sample soles were broken down after 30,000 and 40,000 cycles rendering poor flexing resistance, whereas the upper materials of four samples showed poor flexing endurance with break pipiness scale ratings $4 / 5$ and 4 before desired 50,000 cycles. Especially sole adhesion and flexing endurance properties should be ameliorated to gratify customers' expectations. KEY WORDS: casual shoe, comfort, chemical test, physical test, quality

\section{INVESTIGAREA ŞI EVALUAREA CALITĂTII CONFORTULUI ÎNCĂLJĂMINTEI LEJERE A MARILOR BRANDURI DIN BANGLADESH UTILIZÂND METODE STANDARD DE TESTARE FIZICĂ ŞI CHIMICĂ}

REZUMAT. În procesele de fabricare a încălţămintei se utilizează mai multe materiale şi substanţe chimice care sunt responsabile pentru un produs de bună calitate. În zilele noastre, de pe actuala piaţă din Bangladesh reiese că marile branduri care vând cu amănuntul nu furnizează clienţilor încălţăminte de bună calitate. Scopul acestui studiu a fost de a investiga diferitele proprietăţi fizice şi chimice ale materialelor pentru pantofi care contribuie la caracteristicile de confort. Au fost testate zece perechi de pantofi lejeri din piele provenind de la cele mai importante cinci puncte de vânzare cu amănuntul din Bangladesh, alese pe criterii precum preţul egal şi cel mai bine vândut articol. Aceste eşantioane au fost supuse unor încercări fizice şi chimice diferite, în conformitate cu metodele standard SATRA (Asociația de Cercetare pentru Încălțăminte şi Domenii Conexe), IUP (Uniunea Internaţională pentru Testare Fizică) şi SLC (Societatea Chimiştilor Pielari), cum ar fi rezistenţa la flexiune a întregului pantof, aderenţa tălpii, rezistenţa la flexiune a materialelor pentru feţe, rezistenţa la flexiune a tălpii SATRA-BATA, temperatura de contracţie, conţinutul de crom în procente (exprimat în \% Cr2O3), absorbţia apei, permeabilitatea la vaporii de apă şi pH-ul. Toate probele au prezentat o aderență slabă a tălpii, deoarece s-au înregistrat valori ale forţei medii de desprindere de $13,9 \mathrm{~kg}, 14,2 \mathrm{~kg}$ şi $20,1 \mathrm{~kg}$ în zona degetelor, în zona metatarsofalangiană, respectiv în zona călcâiului, care au fost cu mult sub valorile standard. Trei tălpi de probă s-au rupt după 30.000 şi 40.000 de cicluri, demonstrând o rezistenţă slabă la flexiune, în timp ce materialele pentru feţe ale celor patru eşantioane au prezentat o rezistenţă slabă la flexiune, obţinând notele $4 / 5$ şi 4, înainte de a finaliza cele 50.000 de cicluri. Proprietăţile de aderenţă a tălpii şi de rezistenţă la flexiune ar trebui îmbunătăţite în mod special pentru a satisface aşteptările clienţilor.

CUVINTE CHEIE: încălţăminte lejeră, confort, test chimic, test fizic, calitate

\section{ENQUÊTE ET ÉVALUATION DE LA QUALITÉ DE CONFORT DES CHAUSSURES LÉGÈRES DE GRANDES MARQUES DU BANGLADESH À L'AIDE DE MÉTHODES STANDARD D'ESSAI PHYSIQUE ET CHIMIQUE}

RÉSUMÉ. De nombreux matériaux et produits chimiques sont utilisés dans les processus de fabrication des chaussures et sont responsables d'un produit de bonne qualité. De nos jours, le marché actuel au Bangladesh montre que les grands détaillants ne fournissent pas de chaussures de bonne qualité à leurs clients. Le but de cette étude était d'examiner les différentes propriétés physiques et chimiques des matériaux de chaussure qui contribuent aux caractéristiques de confort. Dix paires de chaussures légères en cuir provenant des cinq principaux détaillants du Bangladesh ont été testées, sélectionnées sur la base de critères tels que le prix égal et le produit le plus vendu. Ces échantillons ont été soumis à différents essais physiques et chimiques conformément aux normes SATRA (Association pour la Recherche sur la Chaussure et les Domaines Connexes), IUP (Union internationale pour les Essais Physiques) et SLC (Société des Chimistes du Cuir), telles que la résistance à la flexion de la chaussure entière, l'adhérence de la semelle, la résistance à la flexion des matériaux pour la tige, la résistance à la flexion de la semelle SATRA-Bata, la température de rétraction, la teneur en chrome en pourcentage (exprimé en \% Cr2O3), l'absorption de l'eau, la perméabilité à la vapeur d'eau et le pH. Tous les échantillons ont présenté une adhérence de la semelle réduite, enregistrant des valeurs moyennes de la charge de séparation de 13,9 kg, 14,2 kg et 20,1 kg dans la région des doigts, dans la région du gros de l’orteil et dans la région du talon, respectivement, étaient bien en dessous des valeurs standard. Trois échantillons de semelles se sont cassés après 30000 et 40000 cycles, démontrant une faible résistance à la flexion, tandis que les matériaux pour la tige des quatre échantillons ont présenté une faible résistance à la flexion, obtenant les marques $4 / 5$ et 4 avant de compléter les 50000 cycles. Les propriétés de l'adhérence de la semelle et de la résistance à la flexion doivent être spécifiquement améliorées pour répondre aux attentes des clients.

MOTS CLÉS: chaussures légères, confort, essai chimique, essai physique, qualité

\footnotetext{
* Correspondence to: Amal Kanti DEB and Manjushree CHOWDHURY, Institute of Leather Engineering and Technology, University of Dhaka, Dhaka-1209, Bangladesh, debak.ilet@du.ac.bd
} 


\section{INTRODUCTION}

Nowadays a pair of shoes is not only used for the protection of feet but also it has a great fashion value. There are seven basic styles of shoes such as oxford, derby, casual, moccasin, court, boot and sports; among these styles casual shoe is mostly used in Bangladesh for its convenient features such as unlaced and wider opening area with elastic. There are different parts of a shoe such as upper, lining, inter-lining, toe-puff, counter-stiffener, insole, midsole, shank, heel and outsole etc [1]. There are different materials which are used in different parts of a shoe, such as leather, synthetic, mesh as upper and lining materials; leather and synthetic along with poly urethane (PU) or latex foam are mostly used as insole material; a piece of metal is used as shank board between the insole and outsole, various types of outsole such as poly urethane (PU), poly vinyl chloride (PVC), thermo plastic rubber (TPR), vulcanized rubber (VR) and phylon are mostly used in shoe making. Each and every components or parts of a shoe should ensure some standard test values with a view to manufacturing good quality shoes and satisfy customer's needs. The standard values of related tests can vary from one style to another and also from one construction to another. At present, it has been a buzzing word in Bangladesh that most of the popular footwear brands are manufacturing its goods with low quality materials and customers are facing severe problems about sole adhesion failure and materials deterioration of their shoes. The aim of this study was to investigate the different quality aspects of casual shoes, bought from leading five retail brands of Bangladesh.

There are several attributes which are responsible for making the shoe qualityful and comfortable. Garvin introduced the five approaches to define quality such as transcendent, product, user, manufacturing and value based [2]. Transcendent based definition of quality: "Quality is neither mind nor matter, but a third entity independent of two, even though quality cannot be defined, you know what it is [3]." Product based definition of quality: "Quality refers to the amounts of the unpriced attributes contained in each unit of the priced attribute [4].
User based definition of quality: "Quality is the degree to which a specific product satisfies the wants of a specific consumer [5]. Manufacturing based definition of quality: "Quality means conformance to requirements [6]. Value based definition of quality: "Quality is the degree of excellence at an acceptable price and the control of variability at an acceptable cost [7]. There are eight dimensions of quality such as performance, features, reliability, conformance, durability, serviceability, aesthetics and perceived quality. On the other hand, comfort can be defined as a feeling of relaxation and well-being [8]. Comfort is a subjective perception that is based on several variables, such as shape of the foot, foot sensibility, inside shoe climate, pressure on the foot, the vertical impact and shock absorption as well as pressure on the foot [9-11]. Mechanical and thermal characteristics of shoes are the major two drivers of comfort [12]. Air space and ventilation system inside the shoe are the crucial factors for thermal comfort which should be considered at the design phase of the shoe to impart coolness and comfort [13]. On the other hand, flexibility, softness, durability and reduced weight are the mechanical factors for shoe comfort. Moisture disposal means water vapor of shoe upper has been identified as one of the most influential factors for shoe comfort which absence creates moisture saturation that is responsible for bad odor inside the shoe rendering discomfort [14-15]. Flexibility of upper materials and sole flexibility enhance ankle joint movement that ultimately lessen metabolic and respiratory cost which are also found as quality features of shoe [16-17]. Weight of the shoes also has a great influence over comfort properties that is recommended to be less than $500 \mathrm{gm}$ whereas every $100 \mathrm{gm}$ increase in footwear mass can add energy expenditure by $0.7-1 \%[16$, 18]. Proper size \& fit, cushioning, flexibility, light weight, breathability, arch support and toe room allowance was found as the most vital factors for shoe comfort [16]. A study was conducted in Ethiopia to find the performance of leather uppers of footwear where average tear strength, tensile strength, percentage of elongation of upper and color fastness test reports were below than the standard value [19]. 
From literature review, it has been found that there were several studies about thermal comfort and different ergonomic factors for shoe comfort which were mostly survey based but most surprisingly to find that very little study was conducted to reveal the actual quality features through standard tests that are responsible for comfort shoes. To best of our knowledge, there were no study on shoe testing values of leading retail brands of Bangladesh which are prerequisite for quality and comfort shoes. In our previous study, we have unveiled the purchasing factors and comfort features of shoes; now this study will reveal the actual scenarios of shoes quality of leading retail brands that will help the customers to choose their reliable brand as well as retailers will get their products testing report through which they can take necessary measures to amplify the quality features of shoes.

\section{EXPERIMENTAL}

\section{Materials and Methods}

\section{Study Area}

The study area comprises most popular footwear brands of Bangladesh. A field survey was conducted among 200 participants in order to know the most popular brands in Bangladesh by the customers. After analyzing the collected data, it was found that Apex, Bata, Orion, Bay and Jennys are the leading footwear retail brands in Bangladesh. In contrast, sample shoes were undergone different physical and chemical test methods to investigate the quality features of sample shoes with available lab facilities.

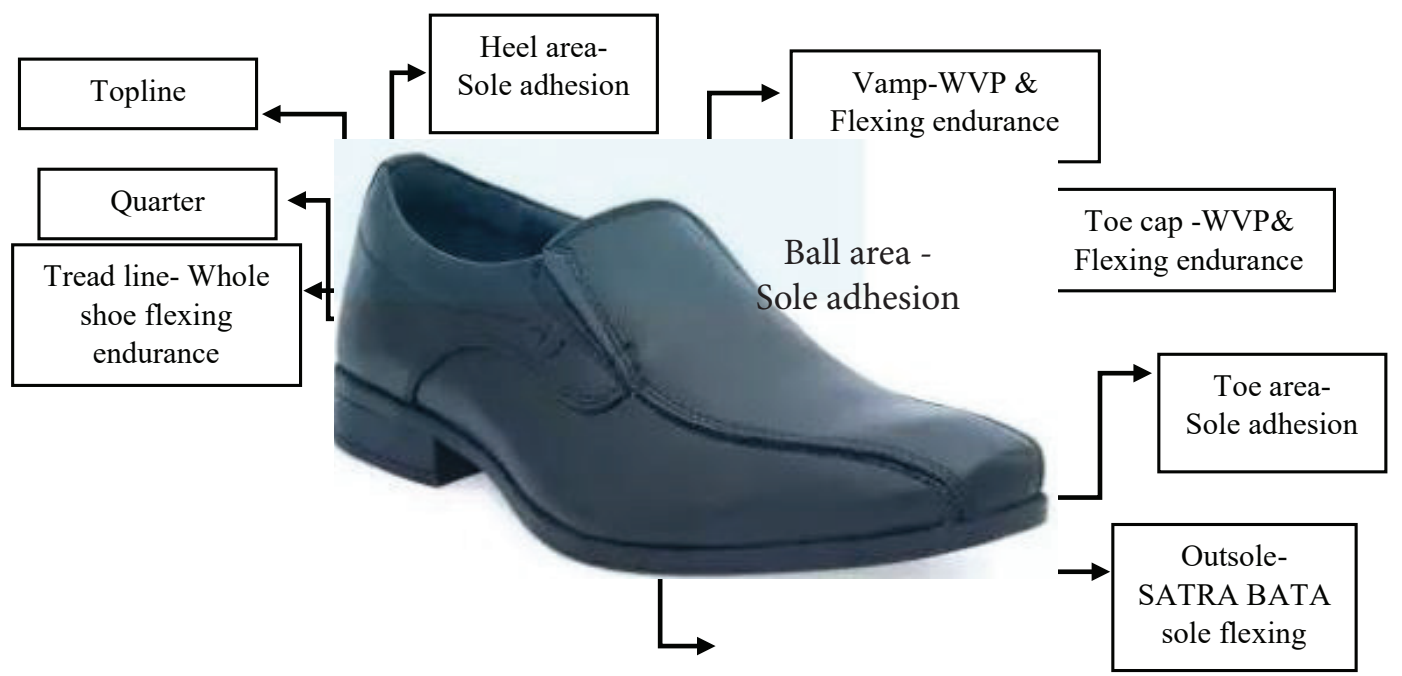

Figure 1. Different parts of a casual shoe with major physical tested sample area

\section{Sample Collection}

Since there were different articles in a store of those brands with different price points, it was very difficult to collect a sample and compare among these. After analyzing the sales trend with the help of respective brand, it was observed that a casual shoe which price of TK 2490 was the best-selling article of all brands. Total 10 pairs of sample casual shoes with 2 pairs from each brand were bought from respective outlets for the quality features that are expressed as B1, B2, B3, B4 and B5.

Table 1: Upper, lining and soling materials of samples

\begin{tabular}{cccc}
\hline Sample & Upper material & Lining material & Soling material \\
\hline B1 & Semi-aniline leather & Coated split leather & Polyurethane (PU) \\
B2 & Semi-aniline leather & Fabric & Polyurethane (PU) \\
B3 & Coated split leather & Coated split leather & Polyurethane (PU) \\
B4 & Semi-aniline leather & Fabric & Thermoplastic rubber (TPR) \\
B5 & Aniline leather & Fabric & Polyurethane (PU) \\
\hline
\end{tabular}




\section{Physical Tests}

Several physical tests were carried out for evaluation of existing quality features of those brand sample shoes following standard methods. Those physical tests were whole shoe flexing endurance test-SATRA PM 92, water vapor permeability test of upper leather- IUP 15, flexing endurance of upper leather-SATRA PM 55, SATRA Bata Belt sole flexing-SATRA TM 133, sole adhesion test-SATRA AM 04 and shrinkage temperature-IUP 16 and water absorption-IUP 7.

\section{Chemical Tests}

There are some tests those are related with directly or indirectly with the ideal properties of shoe which were conducted as per standard methods. Those tests were determination of chrome content as per SLC 8 (IUC; BS 1309:8) and determination of $\mathrm{pH}$ as per IUP 11.

\section{Instruments}

Various international lab standard equipment, instruments and glass accessories were used for all physical and chemical tests. Following instruments had been used for the methods performed for different tests- $\mathrm{pH}$ meter (Orion perpHect LogR meter model 370), shrinkage machine (SATRA STD 114), water vapor permeability machine (SATRA STM 473), bally flexometer 2396, SATRA/BATA belt flexing machine (SATRA STM 459), sole adhesion testing machine (SATRA STD 185) and whole shoe flexing machine (SATRA STM 184).

\section{RESULTS AND DISCUSSION}

Since there were 2 pairs of shoes per brand, in total 10 pairs of shoes; results were made by average of 2 pair of shoes for each brand that was identified as B1, B2, B3, B4 and B5. Some test results were reproduced and standard deviations is showed in the graph as error bar.

\section{Results of Physical Test}

\section{Whole Shoe Flexing Test}

This test was carried out by following standard method SATRA PM 92 with SATRA whole shoe flexing machine at room temperature (25 $\left.{ }^{\circ} \mathrm{C}\right)$. The result is depicted in the table as given below.

Table 2: Whole shoe flexing observation

\begin{tabular}{ccccc}
\hline SL No. & Sample Name & No of revolution & Observation & Remark \\
\hline 01 & B1 & 300,000 cycles & No visual crack found & Acceptable \\
02 & B2 & 300,000 cycles & No visual crack found & Acceptable \\
03 & B3 & 300,000 cycles & No visual crack found & Acceptable \\
04 & B4 & 300,000 cycles & No visual crack found & Acceptable \\
05 & B5 & 300,000 cycles & No visual crack found & Acceptable \\
\hline
\end{tabular}

Total 300,000 cycles were conducted for this test and observed whether any presence of crack along the tread line of the shoe. After each 50,000 cycles shoes were checked for any kind of damage. After observing total 300,000 cycles, all samples were found crack free. So, the samples were in acceptable condition. All of the samples' upper were made of leather that paved the way for getting high endurance.

\section{Sole Adhesion Test}

Sole adhesion test was carried out following standard method SATRA TM 411 and separation load was identified at 4 points of a sample. Obtained results were averaged per brand and expressed as left and right shoe for each selected 4 portions.
Generally minimum load for separation of sole adhesion test at toe and ball area for men's shoe is $25 \mathrm{~kg}$ and $35 \mathrm{~kg}$ for heel area. SATRA recommends minimum load $3.0 \mathrm{~N} / \mathrm{mm}$ should be followed. From the above result of sole adhesion test it comes to light that each sample was very far below than the standard value. Even no pair of shoes from any brands at any point met the standard value that have emerged as a severe bond failure problem. There are some possible reasons for this bond failure such as chemical preparation technique of upper and soling materials, proper quality of adhesive selection, drying time of adhesive, upper and soling materials quality and lack of applied pressure that should be properly maintained during manufacturing process. 


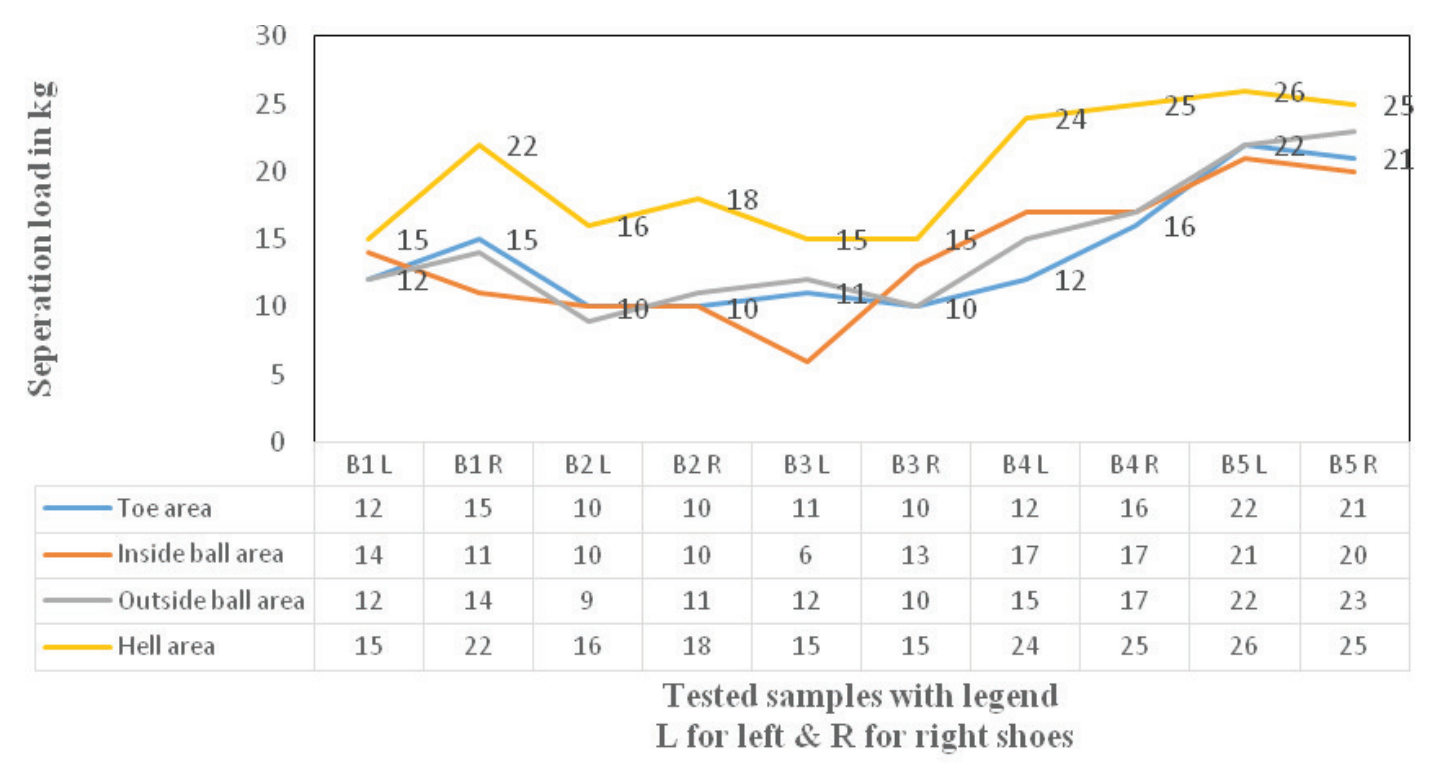

Toe area Inside ball area _- Outside ball area - Hell area

Figure 2. Required load for separation of sole from upper

\section{SATRA-BATA Belt Flexing of Sole}

Table 3: SATRA-BATA belt flexing

\begin{tabular}{ccc}
\hline SI. No & Sample Name & Observation after 50,000 cycles \\
\hline 01 & B1 & No damage \\
02 & B2 & No damage \\
03 & B3 & Damaged \\
04 & B4 & No damage \\
05 & B5 & No damage \\
\hline
\end{tabular}

This test was conducted as per SATRABATA belt flexing method at normal temperature which basically investigate the flexing endurance of sole. There were 5 periods of 10,000 cycles, in total 50,000 cycles and after completing each cycle any kind of damage was observed. As our feet flexes during walking, our shoes have to face several flexing at the time of walking. From the Table 3, it has been observed that the all 2 samples of brand 3 were damaged before predetermined cycle. The poor composition and validity period of PU soling materials may be the reason of this failure. On the other hand, remaining samples showed acceptable result.

\section{Flexing Endurance of Upper Material}

This test was conducted as per IUP 20 standard method which defines the resistance of getting wrinkled against flexing of upper material.

Table 4: Flexing endurance of upper material

\begin{tabular}{ccc}
\hline Sl. No & Sample Name & $\begin{array}{c}\text { Observation after 300,000 cycles } \\
\text { Break pipiness scale rating }\end{array}$ \\
\hline 01 & B1 & 4 \\
02 & B2 & 4 \\
03 & B3 & $4 / 5$ \\
04 & B4 & $3 / 4$ \\
05 & B5 & $2 / 3$ \\
\hline
\end{tabular}


A standard sample $70 \mathrm{~mm} \times 45 \mathrm{~mm}$ was cut and it was faced several repeated flexing of total 6 periods of each 50,000 cycles, and any formation of wrinkle was observed comparing with break pipiness scale rating after completing each cycles; the standard value of this result is 1-3/4. From table 4 , it can be said that only B4 and $B 5$ has met the standard value and remaining samples showed unacceptable results. Coated split leather showed minimum flexing endurance and maximum flexing endurance was found for aniline finished leather.
Water Vapor Permeability of Upper Leather

Almost all upper leathers should be permeable of water vapor because the perspiration formed inside the shoes should go out through the leather to provide comfort to the users. Water vapor permeability is a very important characteristic for upper leather which helps the feet to get comfort and protect any microorganisms' growth inside the shoe.

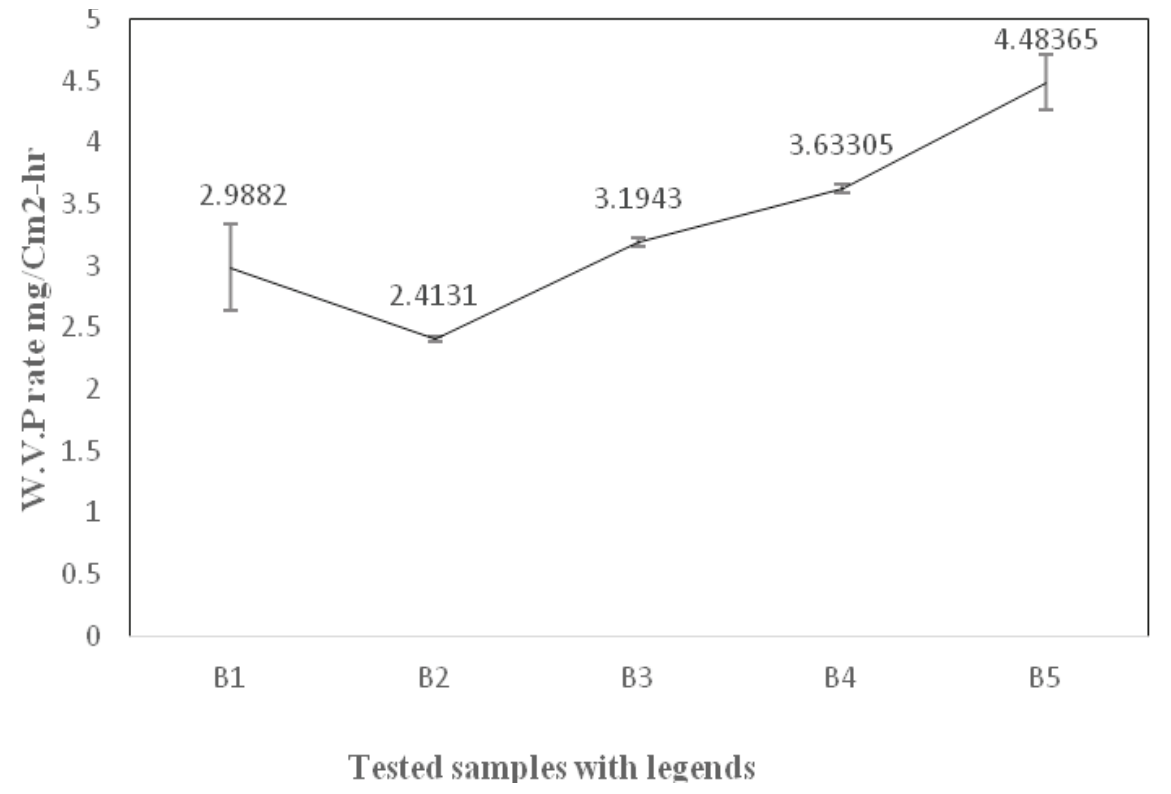

Figure 3. Water vapor permeability of upper leather

This test was carried out following standard method IUP 15 where upper leather should have minimum $0.8-1 \mathrm{mg} / \mathrm{Cm}^{2}$-hr rate of passing vapor. From the above observed data, it has been noticed that all of the samples showed higher water vapor permeability than acceptable value which is congenial for wearers. The reason for this higher permeability was upper materials made of leather.

\section{Determination of Water Absorption}

Least amount of water absorption of leather means good leather. The standard value of water absorption is maximum $30 \%$ after 2 hours [20]. Here \% of water absorption of all leather samples were in acceptable range in the figure 3. Among five brands B4 was comparatively good than other samples. 


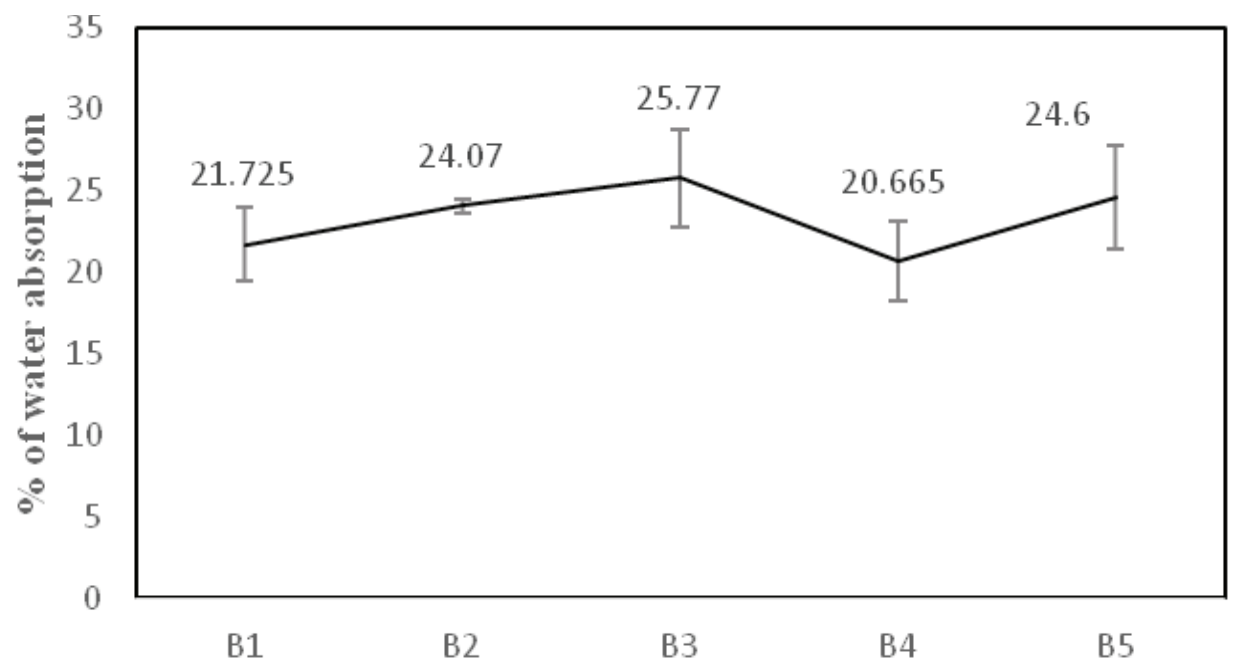

Tested samples with legends

Figure 4. Percentage of water absorption

\section{Determination of Shrinkage Temperature}

Shrinkage temperature definestheresistance power of the fiber of material against particular temperature. Higher shrinkage temperature signifies good quality leather that usually shows 97-105 ㅇ for shoe upper leather [20].

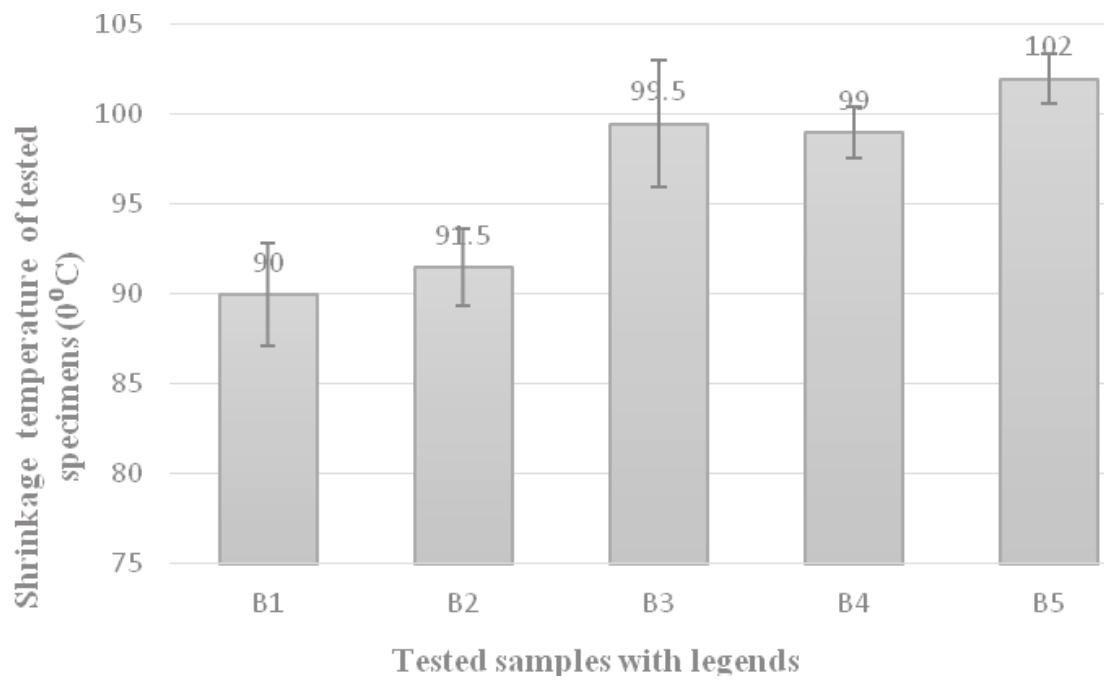

Figure 5. Shrinkage temperature of tested samples

From the figure 5 , it is observed that $B 1$ and $\mathrm{B} 2$ were not in acceptable range but B3, B4 and $\mathrm{B} 5$ were in acceptable range. Since upper materials was leather, maximum of samples showed optimum shrinkage temperature.

\section{Results of Chemical Tests}

\section{Percentage of Chromic Oxide $\left(\mathrm{Cr}_{2} \mathrm{O}_{3}\right)$ Content}

In case of leather tanning chromium $(\mathrm{Cr})$ is mostly used where at least $2.5 \% \mathrm{Cr}_{2} \mathrm{O}_{3}$ should be used for leather tanning and less than $5 \%$ is good
[20]. Least amount of chromium (Cr) content indicates good quality leather which provide light weight leather as well as flexible fiber with enough strength.

On the other hand, excess amount of chromium produces high $\mathrm{Cr}$ content in effluent which has a detrimental effect to the environment. From the experimental data, it is observed that all of the samples were in acceptable range and were chrome tanned leather. 


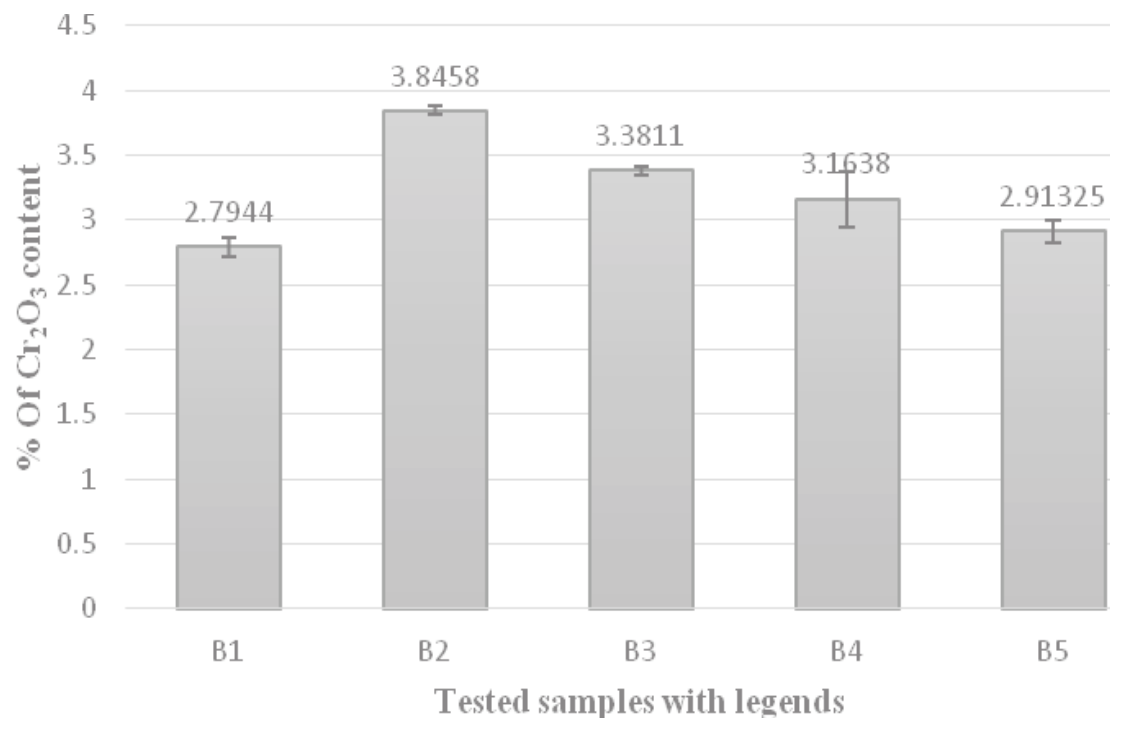

Figure $6 . \%$ of $\mathrm{Cr}_{2} \mathrm{O}_{3}$ content of tested samples

pH Determination of Tested Samples

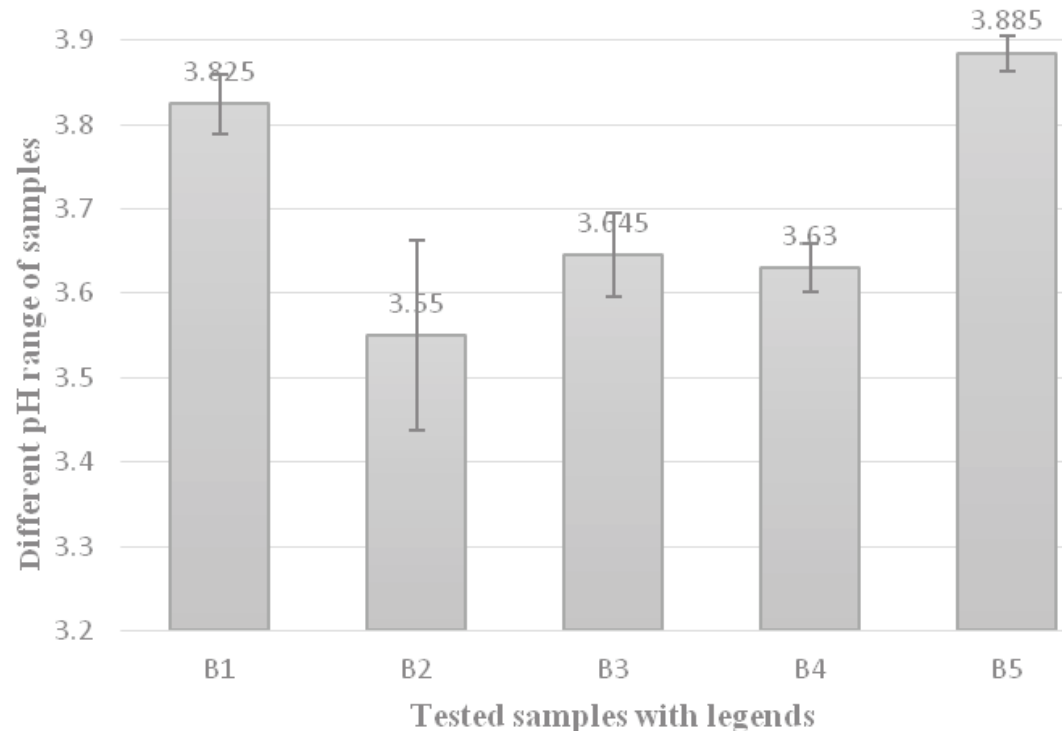

Figure 7. Results of $\mathrm{pH}$ value of different samples

$\mathrm{pH}$ value of all samples were identified as per IUP 11 method where $\mathrm{pH}$ value should not be below than 3.5. Among these results only B2 showed value slightly lower than 3.5; remaining samples were recorded with desired value.

\section{CONCLUSION}

It is very necessary to inspect several features to measure the quality of shoes. Delving into the tested results, it was found that all of the samples showed very poor sole adhesion which will cause separation of sole from upper part before expected life cycle and obviously it will render customer's dissatisfaction. Flexing endurance of upper materials was also poor for two samples which indicates leather will be wrinkled after wearing of these shoes at early period. As all of these samples were made of leather, these showed very high water vapor permeability above acceptable value and also met the acceptable value of these tests, i.e.; water absorption, $\mathrm{pH}, \mathrm{Cr}$ content and whole 
shoe flexing. On the other hand, the two sole samples were damaged in the SATRA-BATA belt flexing showing poor flexing endurance and the remaining samples met the minimum standard value of the test. In order to assess quality features, shoe manufactures should determine these tests prior to bulk production, especially they should ensure the standard value of sole adhesion test because it has been a common problem of all brands. There are lot of reasons for any bad test results that may be identified in pilot production to find out the root causes of problems using cause and effect diagram.

\section{REFERENCES}

1. Miller, R.G., Manual of shoe making, C. \& J. Clarks Ltd., 1980, 169.

2. Garvin, D.A., What does product quality mean?, MIT Sloan Management Review, 1984, 26, 1.

3. Pirsig, R.M., Zen and the art of motorcycle maintenance, 1974, 185, 213.

4. Leffler, K.B., Ambiguous changes in product quality, American Economic Review, 1982, 956.

5. Gilmore, H.L., Product conformance cost, Quality Progress, 1974, 16.

6. Crosby, P.B., Quality is free, 1979, 15.

7. Broah, R.A., Managing quality for higher profits, 1982, 3.

8. Zhang, L.J., Helander, M.G., Drury, C.G., Identifying Factors of Comfort and Discomfort in Sitting, Hum Factors, 1996, 38, 3, 377-389, https://doi. org/10.1518/001872096778701962.

9. Havenith, G., Heus, R., A test battery related to ergonomics of protective clothing, Applied Ergonomics, 2004, 35, 1, 3-20, https://doi. org/10.1016/j.apergo.2003.11.001.

10. Au, E.Y.L., Goonetilleke, R.S., A qualitativestudy on the comfort and fit of ladies' dress shoes. Appl Ergon, 2007, 38, 6, 687-696, https://doi. org/10.1016/j.apergo.2006.12.002.

11. Chiu, M.C., Wang, M.J., Professional footwear evaluation for clinical nurses, Appl
Ergon, 2007, 38, 2, 133-141, https://doi. org/10.1016/j.apergo.2006.03.012.

12. Arezes, P., Neves, M., Teixeira, S., Leão, C., Cunha, J., Testing thermal comfort of trekking boots: An objective and subjective evaluation, Appl Ergon, 2013, 44, 4, 557-565, https://doi. org/10.1016/j.apergo.2012.11.007.

13. Shimazaki, Y., Matsutani, T., Satsumoto, Y., Evaluation of thermal formation and air ventilation inside footwear during gait: The role of gait and fitting, Appl Ergon, 2016, 55, 234-240, https://doi.org/10.1016/j. apergo.2015.11.002.

14. Schols, E., Van den Eijinde, W., Heus, R., A method for assessing thermal comfort of shoes using sweating, Eur J Appl Physiol, 2004, 92, 6, 706-709, https://doi.org/10.1007/ s00421-004-1143-0.

15. Hofer, P., Hasler, M., Fauland, G., Bechtold, T., Nachbauer, W., Microclimate in ski boots - Temperature, relative humidity, and water absorption, Appl Ergon, 2014, 45, 3, 515-520, https://doi.org/10.1016/j. apergo.2013.07.007.

16. Deb, A.K., Shaikh, M.A.A., Sarker, M.R., Hossain, M.I., Assessment of influential factors for purchasing gent's shoes understanding the basic comfort properties, Leather and Footwear Journal, 2018, 18, 1 , 13-24, https://doi.org/10.24264/Ifj.18.1.2.

17. Dobson, J., Steele, J., Riddiford-Harland, D., Effects of wearing gumboots and leather laceup boots on lower limb muscle activity when walking on simulated underground coal mine surfaces, App/ Ergon, 2015, 49, 34-40, https:// doi.org/10.1016/j.apergo.2015.01.006.

18. Jones, B., Toner, M., Daniels, W., Knapik, J., The energy cost and heart-rate response of trained and untrained subjects walking and running in shoes and boots, Ergonomics, 1984, 27, 895-902, https://doi. org/10.1080/00140138408963563.

19. Ashebre, M., Performance of leather uppers of local footwear products and 
the determinants, International Journal of Advancements in Research \& Technology, 2014, 3, 3, 26-30.

20. Dutta, S.S., An introduction to the principles of physical testing of leather, Indian Leather Technologists' Association, 1990, 88,182.
(C) 2019 by the author(s). Published by INCDTPICPI, Bucharest, RO. This is an open access article distributed under the terms and conditions of the Creative Commons Attribution license (http:// creativecommons.org/licenses/by/4.0/). 